\title{
Form and formation of flares and parabolae based on new observations of the internal shell structure in lytoceratid and perisphinctid ammonoids
}

Gregor Radtke, René Hoffmann, and Helmut Keupp

Acta Palaeontologica Polonica 61 (3), 2016: 503-517 doi:http://dx.doi.org/10.4202/app.00154.2015

The ultrastructure of pristine shells of Jurassic and Cretaceous lytoceratid and perisphinctid ammonoids indicates that flares and parabolae represent homologous structures. Both mark an interruption of shell growth. We dismiss earlier interpretations of parabolae as actual aperture, relics of resorbed apophyses or superstructure of the musculature associated to a semi-internal shell. Instead we propose an episodic growth model including several growth stops at the aperture during the formation of a frill-like aperture for parabolae and flares. Such an aperture is composed of the outer prismatic layer, the nacreous layer and an apertural prismatic coating. Here, we observed the apertural prismatic coating for the first time as an integral part of flares and parabolae. The apertural prismatic coating covers only the inner surface of the frill and was secreted by a permanent mantle cover indicating a prolonged period without the production of new shell material. Parabolae differ from flares by their general shape and the presence of ventro-lateral parabolic notches and nodes. The notches were formed by folding of the frill and had the potential to form semi-open spines. The corresponding parabolic nodes are caused by an outward swelling of the shell-secreting mantle tissue producing new shell material at the position of the folding. New shell material that belongs to the conch tube is attached to the base of flares and parabolae after withdrawal of the mantle edge representing the continuation of shell growth. Usually, the frilled aperture associated with flares and parabolae were removed during lifetime. This study reports on flares in Argonauticeras for the first time. In this genus they are typically associated with varices.

Key words: Ammonoidea, ultrastructure,megastriae, temporary aperture, episodic growth, Jurassic, Cretaceous.

Gregor Radtke [gradtke@zedat.fu-berlin.de] and Helmut Keupp [keupp@zedat.fu-berlin.de

], Department of Earth Sciences, Freie Universität Berlin, Malteserstraße

74-100, Building D, Berlin 12249, Germany. René Hoffmann [Rene.Hoffmann@ @ub.de], Department of Earth Sciences, Ruhr-Universität Bochum, Universitätsstraße 150, Building NA, Bochum 44801, Germany. 
This is an open-access article distributed under the terms of the Creative Commons Attribution License (for details please see creativecommons.org), which permits unrestricted use, distribution, and reproduction in any medium, provided the original author and source are credited.

FaF 